\title{
Administrative Learning or Political Blaming? Public Servants, Parliamentary Committees and the Drama of Public Accountability.
}

By Dennis C. Grube

...in our system a political minister must face the music in parliament; that is his duty and his privilege. He must take responsibility for his department and its administration...Civil servants ought not to be dragged into parliamentary debate...it would be deplorable to have their names and views bandied about in Parliament, thus involving the civil servant much against his will in party political controversy.

Sir Robert Menzies (1970, 151-152)

In 1970, former Australian Prime Minister Sir Robert Menzies published a series of political essays - The Measure of the Years - in which he warned against any moves to draw public servants into a more direct type of parliamentary accountability. His argument that public servants should not be called before parliamentarians and compelled to answer questions re-stated what were considered fundamentals of the Westminster system. Ministers, not public servants, provided the public face of government. The doctrine of ministerial responsibility required ministers to answer to parliament and the public for the administration of their departments. Under the traditional public service bargain, a permanent and non-partisan public service would loyally and anonymously carry out the wishes of the government of the day (see Hondeghem 2011). It was not their job to publicly answer for policy outcomes - good or bad (Mulgan 2002: 47).

Things have changed. In part through their appearances in front of parliamentary committees, contemporary public service leaders have become part of the public face of modern government (see Weller 2001: 150-4; Mulgan 2012). Through processes like the annual Senate Estimates hearings in Australia (see Mulgan 2008) opposition politicians now probe for ways to embarrass ministers by embarrassing the public servants who serve them. Under the pressures of a 24/7 news cycle, media outlets use the testimony of public servants as part of their reporting of government performance. Public servants who were once the anonymous instruments of democratically elected governments have become yet another player in the very public blame games that characterize the processes of modern governance.

Many appearances before parliamentary committees display elements of drama, involving 'clashes' between public servants and MPs that are then amplified by being reported in the press. In pursuing a form of accountability that is both public and dramatic, legislatures across the Westminster world have created the conditions in which public

servants can find themselves drawn into the very 'party political controversies' that Menzies was warning against. Accountability, and the form it should take, is an inherently contested 
concept that means different things in different contexts (Bovens et al 2008; ' $t$ Hart and Wille 2006). One stream in the literature suggests that public accountability mechanisms should provide the conditions for bureaucratic 'learning', encouraging best practice public administration for the future (Bovens et al 2008; Aucoin and Heintzman 2000). Bovens et al argue that the characteristics of a 'learning' type of accountability in a public accountability setting have to encourage reflection and debate, but in a 'safe' environment where people can be open without fearing the consequences (Boven et al 2008: 233).

This paper examines the elements of drama inherent in parliamentary committee questioning of public servants, and analyses whether the nature of the setting encourages or inhibits opportunities for a 'learning' type of accountability. The paper is driven by two core research questions:

1. Which elements of 'dramaturgy' are present in the appearance of public servants before parliamentary committees, and what effect do they have?

2. Does the setting of parliamentary appearances facilitate 'learning' accountability or does it encourage blame avoidance behaviour?

\section{Dramaturgy Theory and 'Blame Game’ Theory}

There is a strong and still developing literature on the ways in which policymaking processes can be seen and understood as 'dramaturgy' ('t Hart 1993; Hajer 2005a, 2005b, 2006; Freeman and Peck 2007; Peck et al 2009). Hajer's series of articles in the area argue that the dramaturgy of policymaking contains all the aspects needed in any meaningful piece of theatre: scripting, staging, setting and performance (2005a: 631). Hajer uses dramaturgy theory to examine the mixture of formal and informal policy processes involved in the making of land use and planning decisions (e.g. Hajer 2005a and 2005b). But as the earlier work of Austin (1962) and Edelman (1964) demonstrates, elements of symbolism, performance and dramaturgy are present in most political processes, and parliamentary committees are no exception.

In theory of course, the public service stands impartially aside from 'political' contests. In practice, the processes of public accountability before parliamentary committees insert public servants into the middle of hotly contested political disputes. The fact that these debates are very much public in nature can create perceptions of engagement in political debate, even if in reality public servants are trying very hard to avoid becoming engaged (see Lindquist and Rasmussen 2012: 191). Dramaturgy theory provides a different way of examining the formalised accountability processes of parliamentary committees as political contests in which there are winners and losers. It draws out the inherent tension between the democratic authority of MPs to question the executive and the overriding duty of public servants to loyally support the government of the day. 
By seeing parliamentary committees as a 'setting' through the lens of dramaturgy theory, the format of this institutionalized process of public accountability becomes more apparent. The setting is inherently adversarial, in which MPs adopt the role of interrogators of public servants who are presumed to be withholding vital information from the public about the failures and missteps of the government. It's a performance in which the script is constructed as an opportunity for the people's representatives to discipline the people's servants. Like students summoned to the principal's office, public servants know that they are coming to be scolded by their parliamentary masters. When ministers appear before a committee of their fellow MPs they appear as equals; as democratically elected representatives themselves they have no need to kowtow. For public servants, the power dynamic is different. They are being called before a committee that is trying to either attach blame to them for administrative failures, or recruit them as accomplices to shift blame onto the ministers that they serve. Under the conventions of a Westminster public service, neither outcome is one that public servants can easily embrace.

One of the limitations of dramaturgy theory is that it can't reveal everything about the institutionalised factors that may be driving the way that actors interpret the part they are to play. A second line of theory - 'blame game' theory - provides further insights into what public servants are trying to achieve from their appearances before parliamentary committees. Blame game theory as derived from the work of Christopher Hood (2011; see also Weaver 1986) suggests that looking at the working of bureaucracies through the prism of blame avoidance can help to explain the structure and behaviours of public institutions and the actors within them. Hood identifies three types of blame avoidance strategy. These are 'presentational' strategies that are about the spinning or framing of information to present it in the best possible light; 'agency' strategies that involve organizing a public agency in such a way that responsibility doesn't settle in any one place or on any one person; and 'policy' strategies which see decision-makers adhere to strict policy processes that remove their discretion and therefore provide the defence if something goes wrong that they were 'just following policy'. Faced with the need to deflect or parry blame attribution attempts, public servants appearing before parliamentary committees embrace various of these strategies.

To examine the workings of parliamentary committees as theatrical vehicles for the public attribution of blame, the paper asks three questions about the appearances of public servants: First, what are they allowed to say? What are the rules that govern appearances by public servants? Second, what do they say? What lines of questioning are employed by committee MPs and are they targeting political or administrative matters? And third, what does the media make of what was said? How are bureaucratic appearances portrayed in the press - as politically-charged theatre or as part of the normal business of public administration? 
To analyse these questions through a comparative lens, the paper undertakes two in-depth case studies examining high profile administrative failures in two countries - the United Kingdom and Australia. The cases have been selected under a 'least similar' research design to create an exploratory analysis that will draw out as wide a spectrum of behaviours as possible in how public servants are questioned by parliamentary committees. The first case is the 2012-13 inquiry by the Public Accounts Committee (PAC) in the United Kingdom into the failed tender process for the West Coast rail franchise. The PAC in the United Kingdom has a long-standing tradition of investigation of administrative failures in a largely non-partisan way. In media coverage prior to the inquiry, the case had already been widely reported as a failure of administrative process rather than political leadership. The second case is the 2010 inquiry by the Australian Senate Standing Committee on the Environment, Communications and the Arts into the Rudd government's Home Insulation Program (HIP). Undertaken in a fiercely partisan environment in an election year, the Committee was split along partisan lines and was focussed on failures in political leadership rather than administrative process.

The cases chosen are illustrative of the two ends of a spectrum on how much parliamentary committee investigations are driven by administrative or political questions. They are not intended to be representative in a country-specific sense. In other words, I do not claim that select committees in the United Kingdom always operate in the way that the PAC did in the West Coast rail case, or that Australian Senate committees always operate in the way that they did in the HIP case. Rather, the cases show two distinct ways in which committees can operate, illustrating the breadth of the spectrum that is available to committees in Westminster systems in how they choose to exercise parliamentary oversight of administrative practice.

\section{The Rules - What Are Public Servants Allowed To Say?}

\section{United Kingdom}

In the United Kingdom, the relevant guidelines are known colloquially as the 'Osmotherly' rules after the civil servant who authored them in the early 1980s. The Osmotherly rules like so much of the Westminster system as a whole - are largely convention-based and have no formal authority. This is acknowledged in the rules themselves, which state at the outset that '...this memorandum is a Government document. Although Select Committees will be familiar with its contents, it has no formal Parliamentary standing or approval, nor does it claim to have' (Cabinet Office 2005: para. 3).

In 2012, the House of Lords Select Committee on the Constitution produced a report on the Accountability of Civil Servants. The Committee examined the Osmotherly rules in detail and stressed that: 'The Osmotherly rules are an executive document offering 
guidance to civil servants-and no more. They in no way have the effect of imposing restrictions on the activities of select committees' (House of Lords 2012: para. 70). As noted by the Lords, under the Osmotherly rules civil servants only appear in front of committees 'on behalf of their ministers and under their directions' (House of Lords 2010: para. 74; Cabinet Office 2005: para. 40). In other words, under the doctrine of ministerial accountability, civil servants are not exercising any independent authority when appearing before a committee. They are doing as they are asked on behalf of their legitimate masters - the ministers of the day.

The difficulty arises - that whilst in theory civil servants appear with the face of their minister - the public nature of committee hearings mean that the media can attribute public blame more directly to them. This was acknowledged by Bernard Jenkin MP - whose evidence was cited in the Lords' final report: 'The idea that [civil servants] are unfortunate, beleaguered public servants who cannot speak for themselves is of an era that has passed. They are being held, certainly by the public, to be more directly accountable and it would seem odd if Parliament did not do the same' (House of Lords 2012: para. 77). The Osmotherly rules are aware of the potential for civil servants to be drawn into 'political' debate during select committee appearances, and stress that '[o]fficials should as far as possible avoid being drawn into discussion of the merits of alternative policies where this is politically contentious' (Cabinet Office 2005: para. 55).

\section{Australia}

The Australian guidelines - like the original Osmotherly rules - date from the 1980's. The Government Guidelines for Official Witnesses Before Parliamentary Committees and Related Matters provide guidance on both written and oral evidence, including setting out the limitations that apply to what can legitimately be asked of public servants. Following the Osmotherly approach, the guidelines begin by setting out the broader principles that apply in relation to ministerial responsibility.

In the Australian system of parliamentary government, and consistent with the traditional understanding of ministerial responsibility, the public and parliamentary advocacy and defence of government policies and administration has traditionally been, and should remain, the preserve of Ministers, not officials. The duty of the public servant is to assist ministers to fulfil their accountability obligations by providing full and accurate information to the Parliament about the factual and technical background to policies and their administration. The guidelines are therefore aimed at encouraging the freest possible flow of such information between the public service, the Parliament and the public. (Australian Government 1989: para. 1.1). 
The guidelines make clear that '...officials should be open with committees and if unable or unwilling to answer questions or provide information should say so, and give reasons' (Australian Government 1989: para. 2.19). Coupled with the underlying principle of the 'freest possible flow' of information, there is a clear desire for officials to speak candidly as part of the normal information-sharing process that is considered appropriate in a democracy.

However, the guidelines are careful to express the traditional delineations required of a non-partisan public service, which is that witnesses should not engage with policy opinions but stick to factual explanations about a policy and how it has been implemented. Submissions 'should not advocate, defend or canvass the merits of government policies' (Australian Government 1989: para. 2.15(a)) but 'may describe those policies and the administrative arrangements and procedures involved in implementing them' (Australian Government 1989: para. 2.15(b)). They 'should not identify considerations leading to government decisions or possible decisions, in areas of any sensitivity...' (Australian Government 1989: para. 2.15(c)).

In summary, the rules in the United Kingdom and Australia are largely the same, and in large part re-state the established conventions and traditions of the Westminster system. Ministers are the accountable face of government. Public servants are to provide facts but not opinions, and if in doubt are quite entitled to refer a committee back to ministers rather than answering a contentious question themselves. But in the Australian rules in particular, there is also a principle at play that encourages '...the freest possible flow of such information between the public service, the Parliament and the public.' That principle is in itself something of a departure from engrained Westminster tradition because it suggests a natural link between the public service and the parliament, rather than between the elected government and the parliament.

Having established what the rules are, the next section examines the realities of practice to see how the questioning of public servants by parliamentary committees is actually functioning in a contemporary context. The key challenges in using parliament to hold public servants to account centre on three aspects that the Osmotherly rules and their Australian equivalent are explicitly or implicitly trying to avoid. First, does it contribute to the perceived politicization of public servants by drawing them into political debates? Second, does it diminish ministerial responsibility by holding officials to account rather than democratically elected politicians? And third, does it actually aid in establishing accountability or does it simply encourage the blame avoidance behaviours identified by Hood (2011)? These three aspects are discussed below with reference to the transcripts of hearings from the United Kingdom PAC on the West Coast rail case, and the Australian Senate inquiry into the HIP. 


\section{The Cases}

\section{United Kingdom: West Coast Rail Case}

In the United Kingdom, the West Coast rail franchise bidding process had to be abandoned in 2012 after major administrative mistakes were made, costing taxpayers millions of pounds and leading to direct criticism of the Transport Department. Virgin Rail Group - the existing operator of the West Coast line - lost the tender for the new franchise to the preferred bidder FirstGroup in 2012. Within months, the award of the franchise to FirstGroup was withdrawn after errors were found in how the Transport Department had run the process (see Jupe 2013). The PAC instituted an inquiry and took oral evidence on 13 December 2012, when the permanent secretary of the Department of Transport and the Director General (Corporate) appeared to answer for the alleged mistakes of their department. The PAC brought down its final report in February 2013.

\section{Political Debates:}

On several occasions during the oral evidence, questions were asked about how much the failure of the franchising process could be related to the cuts imposed on the Civil Service by the Chancellor George Osborne. Labour MP Fiona Mactaggert directed a question on the topic to the permanent secretary, Philip Rutnam:

Q115 Fiona Mactaggart: Did you get the basics wrong because you were told that you had to cut spending - that you could not have the right resources to do this? Is that one of the reasons why you got the basics wrong? (House of Commons 2013: Ev 13)

In answer, the Secretary would only acknowledge that resourcing issues contributed to a challenging environment, but that the main reasons had been around effective management and leadership (House of Commons 2013: Ev 13).

The issue was taken up again later during the hearing by Labour MP Austin Mitchell, when discussing what had caused confusion over which senior officer in the Department had been responsible for the project during a crucial three month period. 'Is that anything to do with the heavy turnover of staff, because of the requirement to cut your staff down' (House of Commons 2013: Ev 16)? The Committee Chair, Labour MP Margaret Hodge, joined the exchange by asking: 'Did you not get financial advisers because of the cuts' (House of Commons 2013: Ev 17)? After being pressed, Secretary Rutnam did concede that: 'The environment in relation to using external advisers after the election was clearly to 
avoid them if you can' (House of Commons 2013: Ev 17). Satisfied that this supported his point, Austin Mitchell thanked him for his answer and said: 'Another triumph for the Osborne cuts, it seems to me' (House of Commons 2013: Ev 17).

\section{Ministerial Responsibility}

The question of ministerial responsibility for the bureaucratic failings of the department was conspicuous largely by its absence, and at no point in the discussion was it suggested that it was up to ministers to resign or accept ultimate responsibility for the errors that had been made. The Committee was focused on pursuing the nature of the administrative mistakes and who might be responsible at a departmental level. There was some discussion of whether the department had in fact appropriately briefed ministers, and of the fact that the mistakes had caused considerable public embarrassment at the political level. Chair Margaret Hodge engaged with Director General (Corporate) Claire Moriarty about whether ministers had been made aware of all the details they should have.

Clare Moriarty: I am speaking from recollection because I didn't see the submission at the time, but the submission was similar to the papers that came to the Board Investment and Commercial Committee. From recollection, I think that the information about the relative growth in the bid compared with the achieved growth in recent years wasn't in the submission.

Chair: That was in?

Clare Moriarty: That wasn't in.

Chair: Was not in or was in?

Clare Moriarty: Was not, as far as I recall.

Q34 Chair: Goodness. (House of Commons 2013: Ev 4)

Conservative MP Stewart Jackson pointed out later in the hearing that ministers had not received the full information they should have because of the Department Secretary's exclusion from the decision-making process. He emphasised that ministers had suffered 'serious reputational damage' by being left 'out of the loop' (House of Commons 2013: Ev 14). The question essentially was about who was responsible for having embarrassed ministers, rather than whether ministers should bear ultimate responsibility for the mistakes made. 


\section{'Blame Games'}

Hood's characterization of the 'blame game' as it relates to 'agency strategies' is focused on the design of an organization in such a way that it makes it difficult to pin down blame - to provide a 'buck stops here' sign for any particular desk (Hood 2011: 67). The transcript from the West Coast rail hearing shows that some such 'agency strategies' were in evidence. For example, PAC members were intrigued by arrangements that meant that no one Single Responsible Owner (SRO) had carriage or oversight of the project from the outset. This resulted in a period of confusion when it was not clear which of two possible SRO's was in charge. The Department's Secretary and the Committee Chair discussed the point in at least one exchange, with the Chair asking Rutnam whether he now acknowledged that the internal divided responsibility had been 'mad'. When pressed, Rutnam conceded that he did not 'intend to carry on with that structure in the future' (House of Commons 2013: Ev. $3)$.

There was also a focus from the Secretary and the Director General (Corporate) on collectivizing responsibility for errors across the multitude of bodies within the department that had played a part in the project. These included the 'Contract Award Committee' and the 'Board Investment and Commercial Committee' (House of Commons 2013: Ev 1), legal officers, and mid-level staff who were 'trying to do the best they could' (House of Commons 2013: Ev 16) but hadn't notified their superior officers in time of the challenges being faced.

\section{Media Response}

Whilst the hearings and proceedings of the parliament are of course a matter of public record, in reality the impact of parliamentary committee hearings on public debate is largely mediated by the level of press attention that they attract. During the course of the oral hearings before the PAC on 13 December 2012, newswire services filed stories on the unfolding evidence of the overall costs to the taxpayer of government failure. For example, the Press Association National Newswire posted a story under the headline 'Franchise Fiasco Bill "Could Grow"', quoting the permanent secretary of the Transport Department, Philip Rutnam, as saying that he couldn't guarantee that there wouldn't be further calls on the public purse (Woodman 2012). The story described 'stormy scenes' at the hearing.

The Times also reported on the tenor of the exchanges between the witnesses and MP's on the Committee as 'angry' and how the Department's leaders had 'admitted' to financial waste and getting the 'basics wrong' (Sherman 2012). The Daily Telegraph used Rutnam's words in its headline, writing 'West Coast bid civil servants "penny wise and pound foolish"' (Thomas 2012). None of these articles linked the testimony of the civil servants back to the ministerial responsibility of the appropriate minister. Rather, the focus of coverage was on the evidence of the civil servants in their own right as accepting the 
blame themselves for the maladministration of this particular project. It was a debate about public administration rather than a debate about 'political' responsibility.

The tenor of the coverage remained the same when the PAC published its report into the matter on 26 February 2013. For example, The Guardian described the report as saying '...the aborted west coast franchise award was down to a "complete lack of commonsense" from "blinkered, rushed" senior officials' (Topham 2013). The Daily Telegraph also placed civil servants front and centre, writing that the '...PAC report is more critical about the lack of leadership and the failure of civil servants to learn from mistakes in other projects' (Gribben 2013). The Daily Mirror, under the headline 'LACK OF COMMON SENSE THAT COST US f5OMILLION; Fury at West Coast rail farce', focussed on the 'blinkered' approach of civil servants, and quoted a union leader as saying: 'They could not be trusted to run a whelk stall let alone multi-billion pound contracts' (Ellis 2013). In Liverpool, the Echo bucked the trend by quoting an Opposition MP demanding a degree of ministerial responsibility for what had occurred, suggesting that ministers should not 'hide behind civil servants' (Williamson 2013). The Financial Times (Odell 2013) also suggested that the report 'pointed the finger of blame at ministers.'

Overall, the majority of the media focus was on the alleged incompetence of civil service officials rather than the lack of appropriate oversight or responsibility from ministers. Terms such as 'blinkered' and 'lack of common sense' were directed not at ministers but squarely at their departmental officials. In other words, media coverage very much reflected the Committee's view of the proceedings rather than that of the civil servants. The PAC, through its lines of questioning, provided a framing narrative for what had gone wrong, and the media embraced and amplified that narrative.

\section{Australia: Home Insulation Program}

In Australia, the HIP was one part of a suite of fiscal stimulus measures adopted by the Rudd Government in response to the onset of the Global Financial Crisis. Introduced in 2009, in broad terms the scheme's stated goals were to stimulate the economy by providing large rebates to Australians willing to install roof insulation, and simultaneously to improve energy efficiency in Australian homes. Failures in regulation and the fast-paced implementation of the scheme were widely criticized as at least four insulation installers lost their lives and poor installation practices led to house fires (see Lewis 2012). In October 2009, the Australian Senate Standing Committee on the Environment, Communications and the Arts set up an inquiry into the 'Energy Efficient Homes Package'. The committee took five days of oral evidence, predominantly in Canberra, and questioned at length the public 
servants who had been involved with the design and implementation of the scheme, from across a broad range of government departments and agencies.

\section{Political Debates}

There was a consistent relationship throughout the Committee's hearings between lines of questioning and the political elements of decision-making by ministers. Committee members were willing to push public servants for details and opinions, and public servants were prepared to stand their ground and refuse to answer if they felt a question related to matters going to the provision of advice to ministers. For example, an Assistant Secretary from the Department of Prime Minister and Cabinet refused to answer a particular question in detail 'given the traditions around cabinet in confidence and material going to cabinet' (Official Committee Hansard 2010c: 75).

On some occasions, witnesses were unsuccessful in their attempts to stand their ground, as the following exchange illustrates.

Senator BARNETT-When did you first become aware of the government's plan to put together a \$41 million rescue package?

Mr Griew - I think the question you are asking me goes to the provision of advice that we give to the government-

Senator BARNETT-No, with respect-

Senator BIRMINGHAM-It is a fairly direct question.

Senator BARNETT-Mr Griew, with respect, that is a direct breach of Senate standing orders. I am asking you for the date-not the advice you gave to the government, the cabinet or the minister-when you first became aware of the government's plans to put together a \$41 million rescue package. Can you answer that question, please? (Official Committee Hansard 2010b: 43)

The witness was pressed and went on to provide an answer. In a second instance, Senator Barnett accepted that the witness had a legitimate right not to answer a question on the policy options that were given to a minister because of the accepted convention against revealing policy advice (Official Committee Hansard 2010b: 45).

\section{Ministerial Responsibility}

Whilst seldom explicitly raised, the question of ministerial responsibility was right at the heart of the committee's concerns. Their sharpest questioning was on what ministers were told and when and how they responded. The Committee was probing to establish whether any conclusions could be drawn about any possible dereliction of duty - either by relevant 
ministers or the prime minister. In a sense they were looking for evidence that could be used politically against the executive rather than seeking public service based explanations for alleged administrative incompetency.

There were long lines of questioning regarding a risk assessment report on the program that had been prepared by external consultants Minter Ellison, and when and if ministers had been made aware of the contents of that report (see Official Committee Hansard 2010a, 4-42). These extended into questions of how often ministers were briefed, and whether ministers had been proactive in asking for briefings.

Senator BIRMINGHAM - I want to know the minister's response to this now. I know you have continually updated him. I want to know whether he just sat there like a mute or how he responded. Did he ask for more information? (Official Committee Hansard 2010a: 35)

The Committee was particularly keen to establish whether there had been any ministerial level directives to rush program implementation.

Senator BIRMINGHAM-What instructions about deadlines did the Prime Minister or Parliamentary Secretary Arbib give you at the commencement of the program?

Mr Mrdak-The Prime Minister publicly made clear at the time the urgency of implementing the fiscal stimulus measures, and ministers have reiterated that through the course of the program. The time frames were set out in the National Partnership Agreement, which was agreed by COAG, as Ms Beauchamp has outlined, and the government was very clear about the time frames for the delivery of the program.

Senator BIRMINGHAM-Did the Prime Minister ever tell you that there should be no change to any of the announced time lines?

Mr Mrdak-No, not explicitly. We worked through the time frames that were provided by government to implement the program. (Official Committee Hansard 2010b: 10)

\section{Blame Games}

The apparent focus of the Senate Committee members was less on attributing blame to particular departments - although there were elements of that - but to finding information with which they could sheet home political blame to the government for mistakes made. Nevertheless, in providing information on what ministers had said and done at various times, public servants also exhibited some of the blame avoidance strategies outlined by Hood (2011). For example, there were frequent clarifications provided about the fact that 
different officers were unable to comment on particular things because they had changed position since the events in question. This fits broadly within the 'agency strategies' identified by Hood that enable the avoidance of blame through consistent position churn (Hood 2011: 19). Senators were certainly acutely aware of the issue, as the following exchange illustrates:

Senator BIRMINGHAM - I assume Mr Hoffman and others were involved on a dayto-day basis.

Mr Hoffman-Not personally. I took up my current role on 21 December.

Senator BIRMINGHAM-Okay. That is always convenient.

Mr Hoffman-It is just a fact.

Senator BIRMINGHAM-The moving sands of the Public Service. A couple of times today we have hit this issue of changing faces. (Official Committee Hansard 2010c: 83)

\section{Media Response}

The media coverage of the hearings largely followed the political focus of much of the questioning. The overwhelming focus of pieces - both in newspapers and on television news bulletins - was on Minister Garrett and his handling of matters, including the Minter Ellison report which the Senate Committee was portrayed as having 'extracted' from Minister Garrett's Department at the hearings. Some of the early pieces filed on the same day as the committee evidence was being heard did focus more heavily on the actual evidence being presented by the Departmental Secretary Robyn Kruk. The ABC filed a piece noting the Secretary's apology to the families of installers who died during the program (ABC 2010), and AAP filed a piece under the heading 'Bureaucrats kept damning report from Garrett' (Alexander 2010).

The second day of hearings (26 February) saw a similar range of pre-emptive and then evaluative media coverage. On 26th February, AAP carried a story under the headline 'Top PM officials to front Senate insulation inquiry' and introduced the Coordinator-General Glenys Beauchamp - as '...the bureaucrat responsible for overseeing the government's economic stimulus rollout...' and that she '...heads the list of public servants giving evidence' (AAP 2010a). The following day's newspaper coverage focused on the demotion of the responsible minister - Peter Garret - with a re-shuffle of his portfolio responsibilities (Coorey 2010; Breusch 2010). The Canberra Times reported on the evidence of one senior bureaucrat - Employment and Workplace Relations associate secretary Robert Griew - in relation to whether unions had expressed safety concerns about the program. But once again, the focus was not so much on Griew as on the political culpability of the Rudd 
Government in having ignored the warnings that unions insisted had been given (Beeby 2010a).

The Committee's final report was released on 15 July, and its call for a royal commission into the insulation scheme immediately dominated headlines. For example, AAP began one piece with 'Environment Protection Minister Peter Garrett has dismissed calls for a royal commission into the government's botched insulation scheme as a political campaign by the opposition' (AAP 2010b) and ABC news carried a story headlined: 'Senate urges royal commission into insulation scheme' (Kirk 2010). The following day's newspapers also focussed on the political dimension of the call for a royal commission, emphasising questions of political responsibility rather than departmental or bureaucratic responsibility for the failures and shortcomings of the scheme.

The Advertiser quoted Minister Garrett as saying: 'There's nothing new that has come through in this recommendation that hasn't already been comprehensively addressed by the government' (Advertiser 2010). In Melbourne, The Age ran with the Opposition's promise to hold a royal commission if the government did not, and quoted the Committee Chair's frustrations at departments keeping information secret and ministers not appearing before the Committee (Harrison 2010). The Canberra Times wrote: 'A Senate inquiry into the bungled \$2.5billion home insulation program has called for a royal commission to grill Prime Minister Julia Gillard, senior ministers and top bureaucrats over the scheme's "gross and systematic failures'" (Beeby 2010b).

In summary, in the Australian case, media attention was strongly focused on the political rather than administrative lessons and repercussions to flow from the HIP. Blame was sheeted home to ministers rather than public servants. The debates over the report occurred in the realm of political point-scoring rather than assessing bureaucratic accountability for any of the errors made. As in the British case, this suggests that the media embraced the framing narrative of the majority of committee members, and amplified that story through press headlines. The committee had focussed on who should be held politically responsible and the media followed that focus and framed their stories around alleged failings of political leadership rather than administrative error on the part of public servants.

\section{Significance: The Dramaturgy of Accountability}

The two case studies demonstrate that there is a wide spectrum of current practice in the questioning of public servants by parliamentary committees and in subsequent press coverage. In the Australian case, questioning centred on what ministers knew and when and how they responded to unfolding events. Questioning of public service witnesses whilst leading to some tense exchanges - focused on identifying which ministers could or 
should be held politically responsible for mistakes. There was little direct criticism of public service processes as opposed to political outcomes. The Australian media largely reflected that focus in its reporting. Public servants were not directly blamed or held accountable, and their evidence was utilized only in so far as it helped to shed light on questions of ministerial responsibility.

By contrast, in the United Kingdom case the focus of questioning was squarely on administrative structures and processes and how they contributed to the failure of the tender process. Civil servants were publicly upbraided by MP's on the PAC, with little mention of their ministerial masters. Press reporting followed the Committee's lead. Criticisms - clear, sharp and personal - were levelled at the Transport Department and its bureaucratic leadership. There was also some focus on how a further repetition of such mistakes in the future could be avoided. It was - at both the PAC and the media level - an exercise in administrative rather than political accountability.

There are of course a number of variables that could be contributing to this result. In the United Kingdom, the PAC is a committee with a long tradition of fierce and largely non-partisan scrutiny of government departments. In Australia, the Senate committee hearings in question were instituted in an election year against the background of an opposition narrative criticizing the government for alleged waste and undue haste in the implementation of its fiscal stimulus measures. It was an environment in which fierce partisan disagreement over the home insulation program dominated political debate. The cost in terms of lives lost and money allegedly misspent had already been heavily covered in the media before the committee's investigation, setting the context for the committee to seek to attribute political blame for these failures. This context may help to explain the political focus of the questioning as against the administrative focus in the United Kingdom example.

In terms of dramaturgy theory, the committee hearings in both cases can be said to have served their purpose. They were set-piece adversarial plays in which the people's democratically elected representatives could flex their muscle against non-elected public servants. They created clear stories, with well-defined 'heroes and villains and innocent victims' (Stone 2002: 138) for public consumption. There were two 'scripts' (Hajer 2005a) that the committee members promulgated. Script one, most prevalent in the Australian case, positioned ministers as the guilty parties and public servants as proxies being used to shield their political masters. Script two, most clearly in evidence in the United Kingdom case, positioned civil servants as the guilty party that had to be disciplined - and be publicly seen to be disciplined - by the elected representatives of the people. It was civil servants more than democratically elected ministers that were presented as having let the public down. The effect of the committee hearings in questioning senior bureaucrats was to embarrass them - and in a public way. By doing so in a setting of adversarial theatre, MPs on committees were facilitating accountability to the wider electorate - through the 
amplifying effect of the media. When viewed through the lens of dramaturgy theory, what on the surface appears to be an exercise in public servants being subjected to a form of direct accountability to parliament becomes instead a public act of penance intended for a much wider audience.

The media played their part in the script by amplifying the idea that public servants were on trial. Terms like 'grilling' and 'fiasco' were liberally dotted through the media coverage in the United Kingdom, with the judgmental words of MPs quoted with approval. The committee reports in both cases also provided the certainty of a 'judgment' - a finding on who should be 'blamed' for what had occurred. The blame avoidance strategies identified by Hood (2011) were certainly prevalent, and were to some extent successful in dispersing blame as widely as possible. In the United Kingdom case, the blame landed on the collective desks of the civil servants leading the Transport Department. In the Australian case it settled on the shoulders of the political executive, but did so via the shoulders of public service leaders having to soak up the Senate's anger first. Further media studies in the future will help to reveal whether media coverage of public servants appearing before parliamentary committees has changed over time, and whether this has effected public perceptions of the degree to which public servants should be held accountable.

In both cases, rightly understanding the nature of the 'setting', public servants adopted blame avoidance strategies to defend themselves and their departments from the fierce criticism of committee members. All three of Hood's blame avoidance techniques presentational, agency and policy strategies - were in evidence at various points across the two cases. As the designated 'villains' of the piece, and on the wrong end of a power imbalance in the setting of a committee hearing, public servants reacted by protecting themselves as best they could without compromising their responsible minister. Earlier work by Sulitzeanu-Kenan (2010) examining commissions of inquiry after crisis events suggests that commissions of inquiry are not actually the most effective vehicles for encouraging 'learning' because of the emphasis on finding out who is to 'blame'. The evidence examined in this paper suggests that the same criticism can be made of the appearance of public servants before parliamentary committees.

The cases examined reveal the underlying strengths and weaknesses of engaging public servants in a public form of parliamentary accountability as part of the theatre of government. At one level, the approach in the United Kingdom case will arguably lead the Transport Department to re-double its efforts to avoid the embarrassment that would accompany any repetition of past mistakes. But in doing so, the department and its leaders have had to shoulder the bulk of the accountability for errors that under conventions of ministerial accountability really belonged to their democratically elected leaders. Amidst calls for bureaucratic heads to roll after administrative failures it is easy to lose sight of the importance of Westminster conventions on where responsibility ultimately resides. 
In the Australian case, the focus by the Senate and the press on political accountability upholds the traditional conventions of ministerial responsibility. But in doing so through the questioning of public servants rather than ministers, the process draws public servants into what are largely political rather than administrative debates. The Committee expressed frustration in its final report that the people it had really wanted to question were the ministers who had refused to appear. Public servants were essentially acting as proxies to soak up the political blame intended for their democratically elected superiors. What the process shows is not so much the strengths of the parliamentary scrutiny of public servants, but rather the weaknesses of parliamentary scrutiny of ministers. 


\section{References}

Alexander, C. 2010. Bureaucrats kept damning report from Garrett. Australian Associated Press General News 22 February. Consulted 13 December 2013 via Factiva Database.

AAP [Australian Associated Press]. 2010a. Top PM officials to front Senate insulation inquiry. Australian Associated Press General News 26 February. Consulted 13 December 2013 via Factiva Database.

AAP [Australian Associated Press]. 2010b. Garrett rejects royal commission calls. Australian Associated Press General News 15 July. Consulted 13 December 2013 via Factiva Database.

$A B C$ [Australian Broadcasting Corporation]. 2010. Department head says sorry for insulation deaths. ABC News 22 February. Consulted 13 December 2013 via Factiva Database.

Advertiser. 2010. Garrett rejects insulation inquiry. The Advertiser 16 July: 9. Consulted 13 December 2013 via Factiva Database.

Aucoin, P. and Heintzman, R. 2000. The dialectics of accountability for performance in public management reform. International Review of Administrative Sciences 66: 45-55.

Austin, J. 1962. How to do things with words. Oxford: Clarendon Press.

Australian Government. 1989. Government guidelines for official witnesses before parliamentary committees and related matters. Canberra. URL:

<http://www.aph.gov.au/Parliamentary Business/Committees/Senate Committees?url=wit _sub/gov_full.htm>. Consulted 10 June 2013. 
Beeby, R. 2010a. Union warned Govt on inadequate safety plan. The Canberra Times 27 February: 6. Consulted 13 December 2013 via Factiva Database.

Beeby, R. 2010b. Senate inquiry hits out at Govt's 'systematic failures'. The Canberra Times 16 July: 5. Consulted 13 December 2013 via Factiva Database.

Bovens, M., Schillemans, T. and 't Hart, P. 2008. Does public accountability work? An assessment tool. Public Administration 86(1): 225-242.

Breusch, J. 2010. Combet steps in as Garrett. The Australian Financial Review 27 February: 2. Consulted 13 December 2013 via Factiva Database.

Cabinet Office. 2005. Departmental evidence and response to select committees. URL: <https://www.gov.uk/government/uploads/system/uploads/attachment_data/file/61192/g uide-deptal-evidence-and-response-to-select-committees.pdf>. Consulted 10 June 2013.

Coorey, P. with Hall, L. 2010. The incredible shrinking minister. The Sydney Morning Herald 27 February: 1. Consulted 13 December 2013 via Factiva Database.

Edelman, M. 1964. The symbolic uses of politics. Chicago: University of Illinois Press.

Ellis, M. 2013. Lack of common sense that cost us $£ 50$ million; Fury at west coast rail farce. The Daily Mirror 26 February: 16. Consulted 13 December 2013 via Factiva Database.

Freeman, T. and Peck, E. 2007. Performing governance: A partnership board dramaturgy. Public Administration 85(4): 907-929.

Gribben, R. 2013. Bungled west coast rail contract to cost taxpayer f50m, say MPs. The Daily Telegraph 26 February: 7. Consulted 13 December 2013 via Factiva Database. 
Hajer, M. 2005a. Setting the stage: A dramaturgy of policy deliberation. Administration and Society 36(6): 624-647.

Hajer, M. 2005b. Rebuilding ground zero: The politics of performance. Planning Theory and Practice 6(4): 445-464.

Hajer, M. 2006. The living institutions of the EU: Analysing governance as performance. Perspectives on European Politics and Society 7(1): 41-55.

Harrison, D. 2010. Coalition pledges insulation scheme inquiry. The Age 16 July: 7. Consulted 13 December 2013 via Factiva Database.

Hondeghem, A. 2011. Changing public service bargains for top officials. Public Policy and Administration 26(2): 159-165.

Hood, C. 2011. The blame game: spin, bureaucracy, and self-preservation in government. Princeton: Princeton University Press.

House of Commons. 2013. Department for Transport: lessons from cancelling the InterCity west coast franchise competition. Report by the Committee of Public Accounts. London: The Stationery Office Ltd.

House of Lords. 2012. The accountability of civil servants, $6^{\text {th }}$ Report of the House of Lords Constitution Committee. London. URL: http://www.publications.parliament.uk/pa/ld201213/ldselect/ldconst/61/6102.htm>. Consulted 13 December 2013.

Jupe, R. 2013. New development: Going off the rails? Rail franchising after the cancellation of the West Coast franchise competition. Public Money and Management 33(5): 337-341. 
Kirk, A. 2010. Senate urges royal commission into insulation scheme. ABC News 15 July. Consulted 13 December 2013 via Factiva Database.

Lewis, C. 2012. A recent scandal: the home insulation program. In K. Dowding and C. Lewis, eds. Ministerial careers and accountability in the Australian Commonwealth Government. Canberra: ANU E Press.

Lindquist, E. and Rasmussen, K. 2012. Deputy ministers and new political governance: from neutral competence to promiscuous partisans to a new balance? In $\mathrm{H}$. Bakvis and M. Jarvis, eds. From new public management to new political governance. Montreal \& Kingston: McGill-Queen's University Press.

Menzies, R. 1970. The Measure of the Years. Sydney: Cassell Australia.

Mulgan, R. 2002. Public accountability of provider agencies: the case of the Australian 'Centrelink'. International Review of Administrative Sciences 68: 45-59.

Mulgan, R. 2008. The accountability priorities of Australian parliamentarians. The Australian Journal of Public Administration 67(4): 457-469.

Mulgan, R. 2012. Assessing ministerial responsibility in Australia. In K. Dowding and C. Lewis, eds. Ministerial careers and accountability in the Australian Commonwealth Government. Canberra: ANU E Press.

Odell, M. 2013. MPs pinpoint blame for West Coast rail debacle. Financial Times 26 February: 4. Consulted 13 December 2013 via Factiva Database.

Official Committee Hansard. 2010a. Senate - Environment, Communications and the Arts References Committee. Canberra. 22 February. URL:

<www.aphref.aph.gov.au_hansard_senate_commttee_s12843>. Consulted 10 June 2013. 
Official Committee Hansard. 2010b. Senate - Environment, Communications and the Arts References Committee. Canberra. 26 February. URL:

<www.aphref.aph.gov.au hansard senate commttee s12859>. Consulted 10 June 2013.

Official Committee Hansard. 2010c. Senate - Environment, Communications and the Arts References Committee, Canberra. 25 March. URL:

<www.aphref.aph.gov.au_hansard_senate_commttee_s12937>. Consulted 10 June 2013.

Peck, E., Freeman, T., Six, P. and Dickinson, H. 2009. Performing leadership: towards a new research agenda in leadership studies? Leadership 5(1): 25-40.

Sherman, J. 2012. Taxpayer hit for $£ 6 \mathrm{~m}$ more in rail bid fiasco. The Times 14 December. Consulted 13 December 2013 via Factiva Database.

Stone, D. 2002. Policy paradox: The art of political decision making. London and New York: W.W. Norton and Company.

Sulitzeanu-Kenan, R. 2010. Reflection in the shadow of blame: when do politicians appoint commissions of inquiry? British Journal of Political Science 40(3): 613-634.

't Hart, P. 1993. Symbols, rituals and power: the lost dimensions of crisis management. Journal of Contingencies and Crisis Management 1(1): 36-50.

't Hart, P. and A. Wille. 2006. Ministers and top officials in the dutch core executive: living together, growing apart? Public Administration 84(1): 121-146.

Topham, G. 2013. Transport more rail contracts may be bungled, MPs warn. The Guardian 26 February: 24. Consulted 13 December 2013 via Factiva Database.

Weaver, K. 1986. The politics of blame avoidance. Journal of Public Policy 6(4): 371-398. 
Weller, P. 2001. Australia's mandarins: the frank and the fearless? Crows Nest NSW: Allen and Unwin.

Williamson, D. 2013. Rail fiasco: $\mathrm{mp}$ calls for heads; Report slams collapse of franchise deal. Liverpool Echo 26 February: 4. Consulted 13 December 2013 via Factiva Database.

Woodman, P. 2012. Franchise fiasco bill 'could grow'. Press Association National Newswire, 13 December. Consulted 13 December 2013 via Factiva Database. 